\title{
THE URBAN IDENTITY OF ROMANIAN CITIES REPRESENTED IN STUDENTS' POSTERS
}

\author{
SANISLAI DANIEL \\ Pomi Middle School, Satu Mare County, Romania, e-mail: sanislaidaniel@yahoo.com
}

\section{MARIA ELIZA DULAMĂ}

Babeş-Bolyai University, Faculty of Psychology and Sciences of Education, Department of Exact Sciences Didactics, Cluj-Napoca, Romania, e-mail: dulama@upcmail.ro

\section{OANA-RAMONA ILOVAN}

Babeş-Bolyai University, Faculty of Geography, Department of Regional Geography and Territorial Planning, Cluj-Napoca, Romania, e-mail: ilovanoana@yahoo.com

\author{
VALERIU MIRCEA VANA \\ Babeş-Bolyai University, Faculty of Geography, Cluj-Napoca, Romania \\ e-mail: valeriu_mircea@yahoo.com
}

(Received: June 2016; in revised form: July 2016)

\begin{abstract}
In the first part of the paper, we presented theoretical aspects related to urban identity and to the urban image. In the second part, we presented an exploratory experimental research realised in 2016, at Pomi Middle School, Satu Mare County, Romania. In this activity, students in the $8^{\text {th }}$ grade formed several teams and each team realised a poster, picking as a subject one large city in Romania and presented the characteristic features of that city. Based on our criteria, we analysed those posters by paying attention to what students underlined about the identity of the respective cities.
\end{abstract}

Keywords: urban identity, urban image, analytical assessment grid, poster, experimental research

\section{INTRODUCTION}

A city is a complex geographical space, organised, with a continuous dynamic, having certain features and a variety of distinct functions. Surd and Păcurar (2012, p. 12) pointed out 10 essential functions for the 


\section{SANISLAI DANIEL, MARIA ELIZA DULAMĂ, OANA-RAMONA ILOVAN, VALERIU MIRCEA VANA}

development and evolution of contemporary urban environments: the political-administrative, the civic, the tourism, the financial, the judicial, the transport, the information and communication, the military, and the commercial functions. There are also other functions: the office, the residential, the urban, the environmental, the health, the security, the religious, and the recreational functions. Within the city area, these functions can form various combinations, influenced by population's structure, characteristics, and evolution of the city. In the urban system, certain combinations of functions determine the formation of characteristic territorial areas.

Each city has its own identity, determined by all its features. The urban identity results from its physical or biological components (landforms, climate, water, vegetation, fauna, and soil) and from its anthropogenic components (historical, cultural, socio-economic and environmental - form, structure and texture of the built-up area, architecture, urban landscaping, urban activities - customs, traditions, arts and sports events, social and economic activities -, demography, resources, etc.).

There is significant research on the creation of territorial identity, especially beginning with the 1980s-1990s (Paasi, 1986). Paasi (2002, 2003) considers there is a difference between "the identity of a region" and "regional identity" and this distinction is true also for the identity of an urban area and for urban identity. Namely, "the identity of a region refers to those distinguishing physical, cultural and historical features that make one region different from another. Regional identity (or regional consciousness) refers to the extent to which people identify themselves with the region as the whole of institutionalized practices, discourses and symbols." (Messely et al., 2009, p. 20). Thus, the human component is the one that really gives life to territorial identity, its practices, discourses and symbols differentiating one place identity from another (Boţan and Ilovan, 2007; Ilovan, 2007, 2010; Scridon and Ilovan, 2015, 2016).

The urban identity is built both as a sum and as an integration of place identities. In the urban areas, there may be unique place identities, incomparable ones, which we may easily remember, and place identities built by copying or duplicating, or even by multiplying other place identities. For example, during the communist period, in Romania's cities, many districts were built with identical buildings, with almost imperceptible differences in terms of patterns or shapes.

The identity of a city is formed as a physical-material plan, in a threedimensional reality, but also mentally, as urban images or mental representations of the city. In the urban image creation process, three elements are involved: (a) the real city, (b) the personal sensory experiences, and (c) the mental representation of the real city.

There are two important aspects in the urban image creation: urban legibility and urban imaginability. Legibility expresses the clarity of the urban landscape and the level at which the city can generate a visual quality (Neacşu, 2010, pp. 95-96; Lynch, 1960, pp. 8-13; Ciangă, 2016, p. 51). 
The urban imaginability is the quality of a city to "determine an external observer's perception of a strong image" (Neacşu, 2010, p. 96).

The objectives of this research are:

1) realising and analysing an assessment grid of the urban identity;

2) analysing the contents of students' posters on the urban identity of Romania's large cities;

3) analysing students' results using the assessment grid.

\section{MATERIAL AND METHOD}

We researched a teaching experiment workshop in Pomi Middle School, Satu Mare, 2016. There were six teams of 2-3 members each. In the first stage, each team had to make a research about a big city in Romania, for 2 weeks, and to represent the resulted information on a poster afterwards. The teacher explained the students the importance of the task and offered them a few starting points to guide them in the selection of information, organisation, and layout of their poster. In the second stage, each team presented the poster in front of all teams during the geography class.

Participants. In this research, were involved $8^{\text {th }}$ grade students of Pomi Middle School, Satu Mare County, and the geography teacher, known by students as their teacher, not as a researcher.

Research material. The research subject was the contents of students' posters. Students included the following Romanian cities on their posters: Bucharest, Cluj-Napoca, Timişoara, Iaşi, Constanţa, and Craiova. The contents of the poster was assessed using the conversation method and an analytical assessment scale.

\section{RESULTS AND DISCUSSIONS}

1) Comments on the assessment grid. During the assessment of the posters, for a better and objective evaluation of their contents, we added several elements and categories of elements: localization, surface; natural conditions (landforms, climate, water, and vegetation); place of the city in a hierarchy, in Romania, according to the number of inhabitants; sea ports and rail lines; dolphinarium and gyms or stadia in the category of buildings and touristic places; canals to rivers and landscapes, some city functions (administrative, touristic, commercial, industrial, etc.), and symbols of the city. 
SANISLAI DANIEL, MARIA ELIZA DULAMĂ, OANA-RAMONA ILOVAN, VALERIU MIRCEA VANA

Table 1. Assessment grid for the contents of posters on cities

\begin{tabular}{|c|c|c|c|c|c|c|c|}
\hline \multirow[b]{2}{*}{$\begin{array}{l}\text { Category of } \\
\text { elements }\end{array}$} & \multirow[b]{2}{*}{ Elements } & \multicolumn{6}{|c|}{ City } \\
\hline & & $\begin{array}{l}\text { पू } \\
\frac{d}{D} \\
\frac{1}{U} \\
\frac{C}{D} \\
D\end{array}$ & $\stackrel{\Xi}{\cup}$ & 忍. & 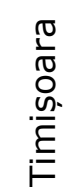 & 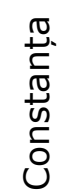 & $\frac{\pi}{\frac{0}{\pi}}$ \\
\hline Localization & Country & $x$ & & $x$ & $x$ & $x$ & $x$ \\
\hline Area & Of the city & & $x$ & & & & \\
\hline \multirow{4}{*}{$\begin{array}{l}\text { Natural } \\
\text { conditions }\end{array}$} & Landforms & & & $\mathrm{x}$ & $\mathrm{x}$ & $\mathrm{x}$ & \\
\hline & Climate & & $x$ & & $x$ & $\mathrm{x}$ & \\
\hline & Water resources & & & $x$ & $x$ & $x$ & $\mathrm{x}$ \\
\hline & Natural vegetation & $x$ & & & & & \\
\hline \multirow{4}{*}{ History } & $\begin{array}{l}\text { Year/period when it was } \\
\text { mentioned in documents }\end{array}$ & $\mathrm{x}$ & & & & $\mathrm{x}$ & \\
\hline & Historic events & & & & & & \\
\hline & Personalities & & & & & $\mathrm{x}$ & \\
\hline & Evolution of the city & $\mathrm{x}$ & & & & $\mathrm{x}$ & \\
\hline \multirow{5}{*}{ Population } & Number & $x$ & $x$ & $\mathrm{x}$ & $x$ & & $x$ \\
\hline & $\begin{array}{l}\text { Place of the city in a hierarchy, } \\
\text { in Romania, according to the } \\
\text { number of inhabitants }\end{array}$ & $\mathrm{x}$ & $x$ & & $\mathrm{x}$ & & \\
\hline & Density & & & & & & \\
\hline & Ethnic structure & & & $x$ & $x$ & $x$ & $x$ \\
\hline & Religious structure & & & & & $x$ & \\
\hline \multirow{9}{*}{$\begin{array}{l}\text { Buildings/ } \\
\text { touristic places }\end{array}$} & Historic and art buildings & $x$ & & & & $\mathrm{x}$ & \\
\hline & $\begin{array}{l}\text { Buildings with historic/artistic } \\
\text { value }\end{array}$ & & & & $x$ & & \\
\hline & Universities & $x$ & $x$ & $x$ & & & $x$ \\
\hline & Churches & & $x$ & $x$ & $x$ & & \\
\hline & Sporting places & & & & & & \\
\hline & Fortresses and castles, palaces & $x$ & & $x$ & & & \\
\hline & Museums & & & & & $x$ & \\
\hline & Aquatic touristic/leisure places & & & & & $x$ & \\
\hline & Sports rooms/Stadia & & $x$ & & & & \\
\hline \multirow{2}{*}{$\begin{array}{l}\text { Landscape and } \\
\text { its design }\end{array}$} & Parks & & $x$ & & & $x$ & $x$ \\
\hline & Public Gardens & & & & & & \\
\hline
\end{tabular}


THE URBAN IDENTITY OF ROMANIAN CITIES REPRESENTED IN ...

\begin{tabular}{|c|c|c|c|c|c|c|c|}
\hline & Belvedere sights & & & & & & \\
\hline & $\begin{array}{l}\text { Recreational forests/ } \\
\text { Park forests }\end{array}$ & & & & & & \\
\hline & Sportive parks/Aquatic parks & & & & & & \\
\hline & Recreation lakes & & & & & $\mathrm{x}$ & \\
\hline & Rivers/Canals & & & $x$ & $x$ & & \\
\hline & Boulevards & & & & & & \\
\hline Streets & Streets & & & & & & \\
\hline squares & Squares and little squares & & $x$ & & & & \\
\hline & Pedestrian areas & & & & & & \\
\hline & Bus stations & & & & & & \\
\hline & Parking places & & & & & & \\
\hline & Railway stations & & & & & $x$ & \\
\hline 10 & Bus stations & & & & & $x$ & \\
\hline & Airports & & & & & & \\
\hline & Seaports & & & & & $x$ & \\
\hline & Maritime stations & & & & & $x$ & \\
\hline & Commercial markets & & & & & & \\
\hline $\begin{array}{l}\text { Commercial } \\
\text { spaces }\end{array}$ & $\begin{array}{l}\text { Commercial centres, shopping } \\
\text { malls }\end{array}$ & & & & & & \\
\hline & Kiosks & & & & & & \\
\hline Cultural/sports & Festivals & & & & & & \\
\hline events & Competitions & & & & & & \\
\hline Functions & $\begin{array}{l}\text { Administrative, } \\
\text { commercial, industrial }\end{array}$ & $x$ & $x$ & & $x$ & $x$ & $x$ \\
\hline Symbol & Of the city & $x$ & & & & $x$ & \\
\hline Total & 50 & 11 & 10 & 9 & 11 & 20 & 7 \\
\hline Share $(\%)$ & & 22 & 20 & 18 & 22 & 40 & 14 \\
\hline
\end{tabular}

2) Analysing the contents of posters. We noticed that the posters were A1 and included photographs and written handwritings (except the text about Bucharest, which was digital). Checking which information sources students preferred, we found out that in many cases they had used Wikipedia. In several keywords searches, such as (names of buildings/landmarks), Wikipedia was the first source offered by Google. We analysed briefly the information about each city and how that information rendered its identity.

Bucharest. We noticed that some information underlined the uniqueness of the city (the most populated and important city in the 


\section{SANISLAI DANIEL, MARIA ELIZA DULAMĂ, OANA-RAMONA ILOVAN, VALERIU MIRCEA VANA}

industrial and commercial fields, being also called "Little Paris"). Other pieces of information focused on the uniqueness and symbol value of its buildings (e.g. The Palace of the Parliament, the University of Bucharest, and Intercontinental Hotel), and monuments (e.g. The Arc de Triomphe). Worldwide, the Palace of the Parliament in Bucharest (also called the People House before 1989), according to the World Record Academy, is the second largest administrative building for civil use according to its area, the most expensive building and the heaviest building in the world.

Cluj-Napoca. The identity of this city is underlined by its features (e.g. having a large university, the second biggest city in Romania according to the number of inhabitants), by the identity of certain places (e.g. Avram Iancu Square), and churches (e.g. The Roman-Catholic Church of St. Michael and the Orthodox Cathedral). The authors of the poster point out that recently its urban image has been associated with the image the Polyvalent Sports Hall and the Cluj Arena, those new buildings hosting some of the national and international sports and cultural events (Figure 1).

Timişoara. Students paid great attention to the identity of this city based on its natural components (meeting point or "divagation area for the Timiş and the Bega rivers", a "frequently flooded swamp area"). The identity is built on three elements: the Metropolitan Cathedral, which is the highest Orthodox Church both in Romania and in the world $(90.5 \mathrm{~m})$ (excluding those in the Russian Federation and Georgia). Other important elements are "Mihai Eminescu" National Theatre and the Bega Canal.

Iaşi. The identity of the city is built due to the sum of urban images belonging to unique buildings, with symbolic value: the Palace of Culture, Three Hierarchs Church, and "Al. I. Cuza" Metropolitan Cathedral, which is dedicated to Saint Paraskeva. We noticed that in the case of the university students paid more attention to its function - "being a public university, of advanced research and education in Iaşi" - rather than to the spectacular building. Students are associating the Bahlui River, even though this does not induce any spectacular features to the city landscape. Students associated atypically Iaşi with other buildings from the surrounding villages (e.g. the Palace in Ruginoasa, and Sturdza Palace in Miclăuşeni), and with presenting information about Iaşi County.

Constanţa. Even if students mixed information about Constanţa County with that of the city itself, in this poster they pointed out many diverse elements of the urban image that give it uniqueness among the studied cities. The authors are aware of the multicultural city features and that is "the sea gate of our country". Students worked with the old symbols of the city (e.g. the Casino, the Genovese Lighthouse) and with the new ones (a boat located at the entrance to the city known as "art exhibit"). For students, the Dolphinarium and Aquarium have great value, those being representative touristic sights of the city. Constanţa is the only city whose image was associated with a personality, his name being Publius Ovidius Naso, the Roman poet who was exiled in Tomis. 
Craiova. The identity and image of this city is built mainly on the University. There was some information about Romanescu Park, the largest park in the city and the largest natural park in Eastern Europe. The authors presented also information about the county (Figure 1).

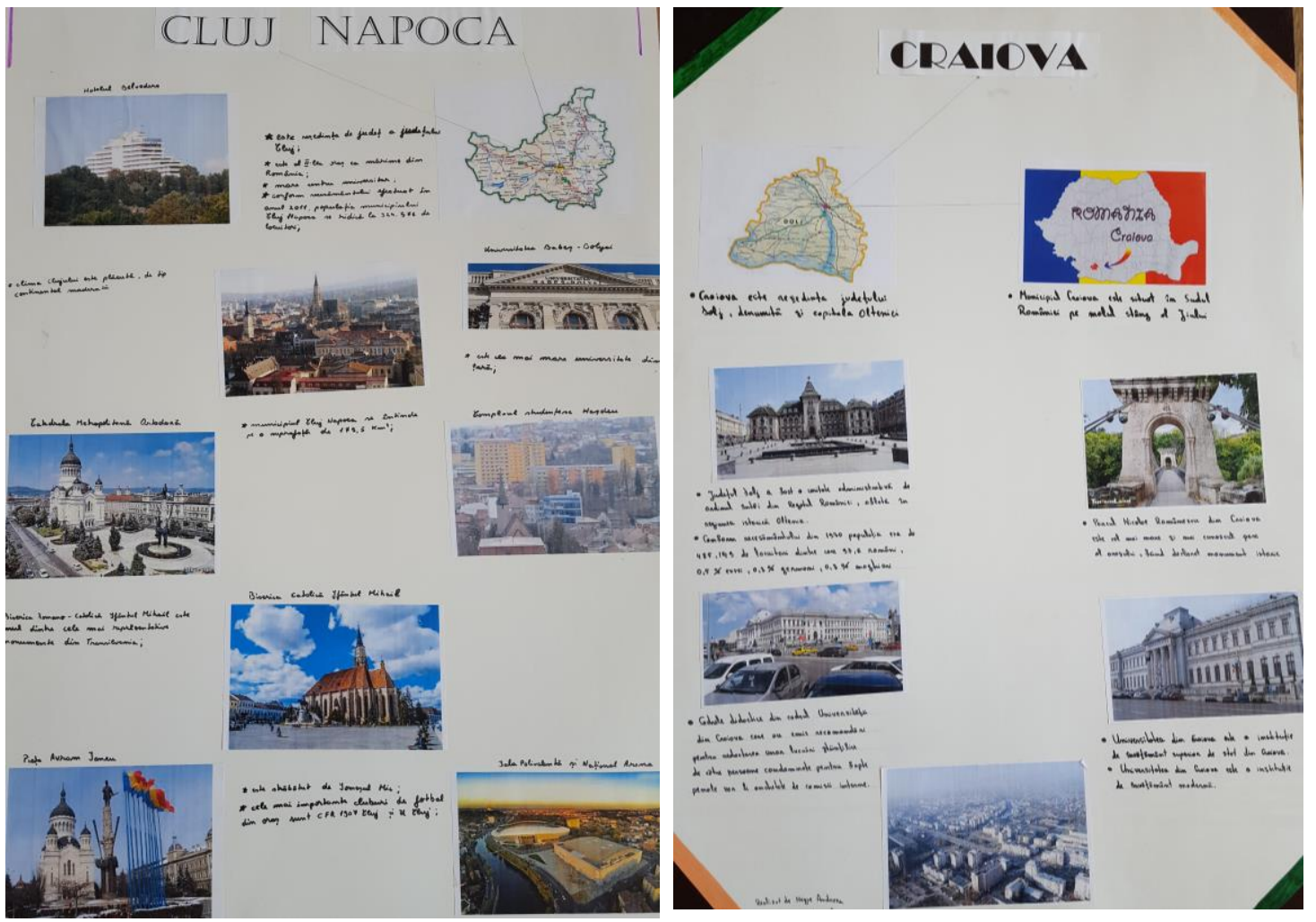

Fig. 1. Two of students' posters

3) Analysis of students' results, using the assessment grid. In Table 1, have marked with $X$ each element of the city presented by students through text and/or photos. By counting the presented elements for each city, the obtained scores varied between seven, given to Craiova city, and 20 for Constanţa city. The maximum score can be 50 .

In Figure 2, we showed the share of elements in building the identity of Romania's cities, computed according to the scores assigned for each city. If we compare the results of each team with the maximum that can be obtained, then both the lowest percentage (14\%) and the highest one $(40 \%)$ are below the threshold of $50 \%$ (the promotion threshold in Romania being 5 , out of 10 ). These results should be interpreted considering the fact that these students did not receive this assessment tool in the early stage of their activity (and feedforward is important in geographical education Dulamă and Ilovan, 2016). In addition, the researchers have enhanced this tool after analysing the contents of their posters.

Analysing the elements that students underlined and looking at Table 1 , one can notice that the city identity and the urban images were built predominantly from some specific categories of elements: location, natural 


\section{SANISLAI DANIEL, MARIA ELIZA DULAMĂ, OANA-RAMONA ILOVAN, VALERIU MIRCEA VANA}

conditions, buildings/touristic objectives. On the one hand, one can notice that the images of buildings/touristic objectives have a stronger impact on students, especially the ones that have a value of symbol and, on the other hand, that they would use information taken from books or Internet network regarding those functions.

Students paid average attention to the history of those cities, landscapes, streets and squares, transportation and parking places, although these types of elements have contributed significantly in the process of building the urban identity and image. The students did not pay any attention to commercial, cultural or sports related spaces, probably because that did not think that this information is relevant for a geographical study.

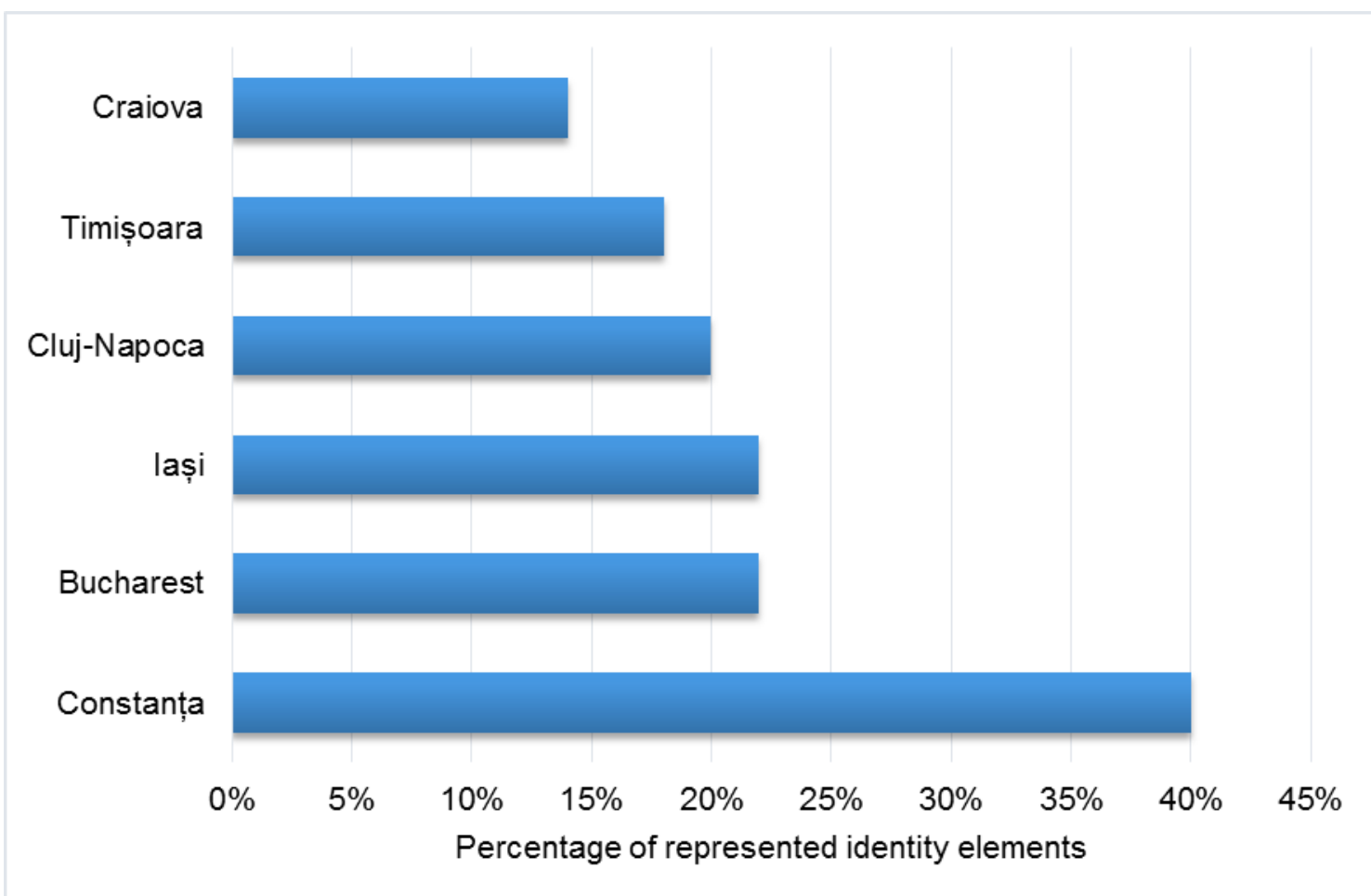

Fig. 2. Share of the represented elements in building the identity of Romanian large cities

In addition, at the Geography of Romania, studied in the $8^{\text {th }}$ grade, students should form their various competences relevant for geography (Table 2) (Ministry of Education, Research and Innovation, 2009). In this experimental activity proposed to students, they are involved into a series of learning activities (Table 2) and have the opportunity to form and develop their competences. They can achieve these competences in other contexts too, using other strategies. However, we underline that for those students, it is important to collect and analyse rigorously and carefully the urban images in order to be able to compare it with other cities in the world, hoping they would be able to appreciate, capitalise, protect, and enhance their beauty. 
Analysing these learning activities, we have noticed that all of them involved performing exercises where the students were able to perceive and understand their mental representation of a city as an urban cultural puzzle and they presented this urban synthesis-image in a collage of texts and photos on a poster. Elaborating the poster, students had the opportunity to not only be simply spectators, but also actively investigate a city, at their cognitive and emotional levels, in order to represent and understand deeply its identity. While realising the posters, students were asked to observe the city not only from the outside, but also from the inside, to place themselves in the position of citizens of the respective city and to understand its identity. This activity is very valuable because the competences formed could be used in other urban contexts, too, irrespective if those are from Romania or, due to the globalization phenomena, from other countries.

Table 2. Geography characteristic competences and learning activities for forming and developing them

\begin{tabular}{|c|c|}
\hline $\begin{array}{l}\text { Geography characteristic } \\
\text { competences }\end{array}$ & Learning activities \\
\hline $\begin{array}{l}\text { 5.1. Identifying geographical } \\
\text { information in databases accessible } \\
\text { via the Internet. }\end{array}$ & $\begin{array}{l}\text { - Searching information about cities on } \\
\text { the Internet; } \\
\text { - Searching photos of } \\
\text { representative/unique places for the } \\
\text { studied cities, on the Internet. }\end{array}$ \\
\hline $\begin{array}{l}\text { 7.2. Employment of simple methods } \\
\text { of investigation } \begin{array}{r}\text { (such as } \\
\text { observation, analysis, } \\
\text { interpretation) of } \\
\text { geographical reality. }\end{array}\end{array}$ & $\begin{array}{l}\text { - Looking at the photographed urban } \\
\text { places/landscapes; } \\
\text { - Analysing the photographed urban } \\
\text { landscapes; } \\
\text { - Interpreting the photographed and } \\
\text { analysed urban landscapes. }\end{array}$ \\
\hline $\begin{array}{l}\text { 7.9. Analysing elements, } \\
\text { phenomena and processes observed } \\
\text { (directly or indirectly) in reality. }\end{array}$ & $\begin{array}{l}\text { - Analysing the city components in } \\
\text { photos; } \\
\text { - Analysing the organisation of urban space. }\end{array}$ \\
\hline $\begin{array}{l}\text { 7.6. Comparing elements, } \\
\text { phenomena, processes, and } \\
\text { territorial structures based on the } \\
\text { required characteristics, identifying } \\
\text { similarities and differences. }\end{array}$ & $\begin{array}{l}\text { - Comparing the photographed urban } \\
\text { landscape to identify those representative } \\
\text { ones for the studied city or the } \\
\text { unique/spectacular ones (critical thinking); } \\
\text { - Comparing the urban landscape of } \\
\text { different cities (from Romania or from } \\
\text { other countries). }\end{array}$ \\
\hline $\begin{array}{l}\text { 1.4. Creating a coherent text using } \\
\text { geographical terms. }\end{array}$ & $\begin{array}{l}\text { - Creating brief scientific texts about the } \\
\text { studied cities, in writing, on a poster. }\end{array}$ \\
\hline $\begin{array}{l}\text { 1.5. Describing geographical } \\
\text { elements, phenomena, processes, or } \\
\text { systems using geographical terms. }\end{array}$ & $\begin{array}{l}\text { - Scientific description of geographical } \\
\text { elements, phenomena, processes, or } \\
\text { systems from the studied city, in writing, } \\
\text { on the poster. }\end{array}$ \\
\hline
\end{tabular}




\section{SANISLAI DANIEL, MARIA ELIZA DULAMĂ, OANA-RAMONA ILOVAN, VALERIU MIRCEA VANA}

\begin{tabular}{|l|l|}
\hline $\begin{array}{l}\text { 7.5. Characterization of the } \\
\text { elements, phenomena and } \\
\text { processes, by observing a given } \\
\text { algorithm. }\end{array}$ & $\begin{array}{l}\text { - Characterization of the city, in writing, } \\
\text { on the poster, observing a given } \\
\text { algorithm; } \\
\text { - Building the identity of the city based on } \\
\text { the analysed information. }\end{array}$ \\
\hline $\begin{array}{l}\text { 7.7. Explaining the (directly or } \\
\text { indirectly) observed elements, } \\
\text { phenomena, and processes. }\end{array}$ & $\begin{array}{l}\text { - Explaining the composition of the urban } \\
\text { landscape as seen in photos. }\end{array}$ \\
\hline $\begin{array}{l}\text { 7.8. Explaining the relationships } \\
\text { between groups of elements, } \\
\text { phenomena, and processes of the } \\
\text { geographical environment. }\end{array}$ & $\begin{array}{l}\text { - Explaining the relationships between } \\
\text { groups of elements, within the urban } \\
\text { landscapes seen in photos. }\end{array}$ \\
\hline $\begin{array}{l}\text { 6.2. Explaining the natural, human, } \\
\text { and cultural diversity of our country, } \\
\text { correlating the information with that } \\
\text { acquired from other subjects. }\end{array}$ & $\begin{array}{l}\text { Explaining the urban cultural } \\
\text { landscape/urban images seen in photos, } \\
\text { capitalising information from History and } \\
\text { Biology. }\end{array}$ \\
\hline $\begin{array}{l}\text { 6.1. Explaining the importance of } \\
\text { Romania's } \\
\text { environment for man and society. }\end{array}$ & $\begin{array}{l}\text { - Explaining the importance of urban } \\
\text { cultural landscapes for the economy } \\
\text { (tourism, trade). }\end{array}$ \\
\hline
\end{tabular}

Moreover, a similar study on representing urban space in students' posters, but from the perspective of the ideal city, was realised by partly the same authors (Dulamă et al., 2012) and showed the advantages of such an educational approach.

\section{CONCLUSION}

In this research, we learnt that students in the $8^{\text {th }}$ grade pointed out many essential features that defined urban identity, even if the quantitative assessment using the analytical assessment grid resulted in low scores. On the posters, students built the urban identity using representative photographs and small amounts of relevant text. Their representations focused on the information taken from various sources about the location, natural conditions, functions, and the images of buildings/monuments with symbolic value, for the studied cities.

The assessment tool designed and tested in this research proved effective and liable for assessing urban identity, and it can be modified and improved when used in other contexts. 


\section{References}

Boţan, C.N., \& Ilovan, O.-R. (2007). Geographic Identity Aspects of the Land of the Moţi. In J.-J. Girardot, M. Pascaru, I. Ileana (eds.), In International Conference of Territorial Intelligence, 2006, Alba Iulia, Romania, Vol. 1, Papers on Region, Identity and Sustainable Development (pp. 87-93). Alba Iulia: Aeternitas.

Ciangă, I.FI. (2016). Peisajul urban în vedutismul transilvan. Cluj-Napoca: Risoprint.

Dulamă, M.E., Ilovan, O.-R., Conţiu, A., \& Conţiu, H. (2012). Representing the Urban Space from the Perspective of the Ideal City. Romanian Review of Geographical Education, 1(1), 43-61.

Dulamă, M.E., Ilovan, O.-R. (2016). How Powerful is Feedforward in University Education? A Case Study in Romanian Geographical Education on Increasing Learning Efficiency. Educational Sciences: Theory \& Practice, (ESTP), Kuram ve Uygulamada Eğitim Bilimleri (KUYEB), 16(3), 827-848.

Ilovan, O.-R. (2007). Mecanisme contemporane în construcţia şi deconstrucţia identităţii regionale în "ţările" din România. Studia Universitatis BabeşBolyai, Geographia, 52(2), 15-20.

Ilovan, O.-R. (2010). Features of the Built Patrimony and the Heritage of the "Lands" in the Romanian Tizsa Basin. Romanian Review of Regional Studies. 6(2), 41-46.

Lynch, K. (1960). The Image of the City. Cambridge: The Technology Press \& Harvard University Press.

Messely, I., Dessein, J., \& Lauwers, I. (2009). Regional Identity in Rural Development: Three Case Studies of Regional Branding. Paper prepared for presentation at the $113^{\text {th }}$ EAAE Seminar "The Role of Knowledge, Innovation and Human Capital in Multifunctional Agriculture and Territorial Rural Development", Belgrade, Republic of Serbia, December 9-11, 2009.

Ministry of Education, Research and Innovation (MECI in Romanian) (2009). School Curriculum. Geography. The $5^{\text {th }}$ to the $8^{\text {th }}$ Grade. Approved by the Ministerial Order No. 5097/09.09.2009. Annex no. 3. București.

Neacșu, M.C. (2010). Imaginea urbană. Element esențial în organizarea spațiului. București: Editura Pro Universitaria.

Paasi, A. (1986). The Institutionalization of Regions: A Theoretical Framework for the Understanding of the Emergence of Regions and the Constitution of Regional Identity. Fennia, 164, 105-146.

Paasi, A. (2002). Bounded Spaces in the Mobile World: Deconstructing "Regional Identity". Tijdschrift voor Economische en Sociale Geografie, 93(2), 137-148.

Paasi, A. (2003). Region and Place: Regional Identity in Question. Progress in Human Geography, 27, 475-485.

Scridon, I., \& Ilovan, O.-R. (2015). The Zipsers' Ethnic Identity in Vişeu de Sus/Oberwischau, Romania, in the Context of Inter-Ethnic Relationships. Mitteilungen der Österreichischen Geographischen Gesellschaft, 157, 151-168. 
SANISLAI DANIEL, MARIA ELIZA DULAMĂ, OANA-RAMONA ILOVAN, VALERIU MIRCEA VANA

Scridon, I., \& Ilovan, O.-R. (2016). Approaching the Other in the Zipsers' Community. Identity Issues and Methodological Insights into Geographical Cross-Cultural Research. Transylvanian Review, 25(1), 55-73.

Surd, V., \& Păcurar, B.N., (2012). The Ecological Function of the City of ClujNapoca. A Functionalist-Heuristic Approach. Journal of Settlements and Spatial Planning, 3(1), 11-19. 